\title{
TELOMERE AND MICROSATELLITE PRIMERS REVEAL DIVERSITY AMONG Sclerotinia sclerotiorum ISOLATES FROM BRAZIL*
}

\author{
LYNDEL W. MEINHARDT ${ }^{1 * *}$, NELSON A. WULFF ${ }^{2}$, CLÁUDIA M. BELLATO ${ }^{1} \&$ SIU M. TSAI ${ }^{1}$
}

${ }^{1}$ Departamento Biologia Celular e Molecular, Centro de Energia Nuclear na Agricultura/Universidade de São Paulo, Av. Centenário, Piracicaba, SP, 13400-970; ${ }^{2}$ Universidade de São Paulo, Escola Superior de Agricultura

"Luiz de Queiroz", Dept. Entomologia, Fitopatologia e Zoologia Agrícola, Av. Pádua Dias, 11,

Piracicaba, SP, 13418-900, e-mail: lyndel@lge.ibi.unicamp.br

(Accepted for publication on 15/01/2002)

Corresponding author: Lyndel W. Meinhardt

MEINHARDT, L.W., WULFF, N.A., BELLATO, C.M. \& TSAI, S.M. Telomere and microsatellite primers reveal diversity among Sclerotinia sclerotiorum isolates from Brazil. Fitopatologia Brasileira 27:211-215. 2002.

\begin{abstract}
Sclerotinia sclerotiorum, the causal agent of white mold, is a problem of winter bean (Phaseolus vulgaris) production in Brazil under center-pivot irrigation. Isolates of $S$. sclerotiorum were obtained from a center-pivot-irrigated field near Guaíra-SP, Brazil. Mycelial compatibility group (MCG) studies revealed the presence of only two MCG. PCR/RFLP analysis of the ITS1-5.8S-ITS2 ribosomal subunit regions of these field isolates of $S$. sclerotiorum failed to show any genetic differences between these two MCGs. DNA amplification with a chromosomal telomere sequence-based

primer and one microsatellite primer revealed genetic polymorphisms among isolates within the same MCG. Isolates taken from beans and two other crops from another region of Brazil showed the same two MCG and had identical banding patterns for the telomere and microsatellite primers. These findings support the use of telomere sequence-based primers for revealing genotypic differences among S. sclerotiorum isolates.

Additional keywords: genetic diversity, mycelial compatibility group, Phaseolus vulgaris.

\section{RESUMO}

Seqüências do telômero e microssatélite revelam diversidade entre isolados brasileiros de Sclerotinia sclerotiorum

Sclerotinia sclerotiorum, o agente causal do mofo branco, causa danos severos na cultura do feijoeiro (Phaseolus vulgaris) na época do inverno em regiões brasileiras que são irrigadas com pivô central. Isolados de $S$. sclerotiorum foram obtidos de uma área sob pivô central perto de Guaíra-SP, Brasil. Estudos sobre o grupo de compatibilidade micelial (GCM) desses isolados revelaram a presença de dois GCM. Análises de PCR/RFLP, com iniciadores conhecidos das regiões ITS1-5.8S-ITS2 não mostraram diferenças genética entre os isolados. Entretanto,

diversidade genética entre isolados pertencentes ao mesmo GCM pôde ser observada através da amplificação da região cromossomal com iniciadores baseados na sequência do telômero e um microsatélite. Os mesmos GCM e perfil de bandas obtido com os iniciadores teloméricos também foram observados em $S$. sclerotiorum isolados de diferentes culturas de outras regiões brasileiras. Os resultados obtidos comprovam que as sequências do telômero podem ser usadas para revelar diferenças genotípicas entre isolados de $S$. sclerotiorum.
\end{abstract}

One of the major problems of highly mechanized irrigated winter production of common beans (Phaseolus vulgaris L.) and other vegetable crops in tropical regions of the states of São Paulo and Minas Gerais is white mold caused by the fungus Sclerotinia sclerotiorum Sacc. (Valarini \& Spadotto, 1995). During the dry winter months in these states, crops must be grown under center-pivot irrigation, which along with lower ambient temperatures create a microclimate that is suitable for infection and growth of S. sclerotiorum.

Previous studies have shown that $S$. sclerotiorum populations in canola (Brassica napus L. var. napus) in

\footnotetext{
*Financial support: in part by a grant from the Fundação de Amparo à Pesquisa do Estado de São Paulo (FAPESP) 1995/9557-8.

**Current address of Lyndel W. Meinhardt is Laboratório de Genômica and Expressão, Departamento de Genética e Evolução, Instituto de Biologia/UNICAMP, Cx. Postal 6109, 13083-970, Campinas-SP.
}

Canada and cabbage (Brassica oleraceae L. var. capitata) in the United States are clonal and that isolates could be separated into distinct mycelial compatibility groups (Kohn et al., 1991; Cubeta et al., 1997). Moreover, genetic analyses have shown that isolates of $S$. sclerotiorum are homogenous with limited variability in the $18 \mathrm{~S}$ and $28 \mathrm{~S}$ rDNA regions (Kohn et al., 1991) and the only useful genetic markers appear to be within a dispersed repetitive element (Kohn et al., 1991).

An initial survey of $S$. sclerotiorum isolates from one region of the state of São Paulo was conducted to evaluate their genetic variation and make comparisons with a few isolates from another highly mechanized irrigated region in Minas Gerais. A secondary goal of this project was to search for genetic markers within this fungal species. The following were evaluated: a) the genetic variation of a limited number of Brazilian isolates, b) common trends within Brazilian 
groups and with known trends of populations from Canada and the USA, and c) the usefulness of telomere sequencebased and microsatellite PCR primers. The findings and conclusions based on this initial survey are reported here.

A field survey was conducted in September of 1996 near Guaíra, in the north central region of the state of São Paulo. Three sampling areas of approximately $10 \mathrm{~m}^{2}$ were selected, roughly $40 \mathrm{~m}$ apart from each other, under the same center-pivot irrigation unit. Within these areas a minimal of three sampling sites were randomly selected. Each sampling site was $0.5 \mathrm{~m}^{2}$ and a minimum of six sclerotia was taken from each sampling site. A fourth area was selected for sampling approximately $1 \mathrm{~km}$ from the center-pivot. Only one sampling site was selected at this location. Isolates derived from the sclerotia were designated CASS ( $\underline{\mathrm{CEN}} \underline{\mathrm{A}} \underline{\mathrm{S}}$ clerotinia sclerotiorum). The isolates CASS1C and 1D were acquired from sclerotia of infected beans grown in another location in the Guaíra region in June of 1996. These infected plants were removed from the field and brought back to the lab. The isolates were obtained from the mycelia and sclerotia that covered the plants.

Isolates $\mathrm{BI}_{14}$, from potato (Solanum tuberosum L.), $\mathrm{F}_{2} \mathrm{PI}_{8}, \mathrm{~F}_{2} \mathrm{I}_{1}$, and $\mathrm{F}_{1} \mathrm{~W}_{9}$, from common beans, and $\mathrm{P}_{2} \mathrm{PNI}_{21}$, from bell peppers (Capsicum annuum L.) were obtained from sclerotia taken from infected plants in 1997 from a region of irrigated production between the cities of Unai and Bomfinópolis in the northwestern region of state of Minas Gerais.

Sclerotia collected from the field were surface disinfected by washing them for $10 \mathrm{~min}$ in $70 \%$ ethanol. The sclerotia were briefly flamed and cut into halves and placed onto petri dishes containing a thin layer of potato dextrose agar (PDA) media. Amended water agar (15 g agar/l water plus $50 \mu \mathrm{g} \mathrm{ml}^{-1}$ spectinomycin and $50 \mu \mathrm{g} \mathrm{ml}^{-1}$ kanamycin sulfate) at $42{ }^{\circ} \mathrm{C}$ was poured over the sclerotia halves, thus embedding the sclerotia in agar. Plates were placed at $4{ }^{\circ} \mathrm{C}$ for four weeks. A single hyphal tip was transferred to a new PDA plate. All genetic analyses were conducted with these cultures. Table 1 lists the isolates used in this study.

Mycelial compatibility groups or MCGs of $S$. sclerotiorum represent genetically distinct groups that are genotypically unique and genetically uniform (Kohn et al., 1991). MCGs differ from vegetative compatibility groups (VCG) in that nitrate utilization mutants are not required (Ford et al., 1995) to conduct this analysis (Kohn et al., 1990 \& 1991). In this study, isolates were grouped into mycelial compatibility groups according to the method described by Kohn et al. (1990) and Ford et al. (1995). Sclerotinia sclerotiorum isolates were paired on modified Patterson's medium with red food coloring. Cultures were incubated at $21{ }^{\circ} \mathrm{C}$ in the dark for 14 days with results recorded at seven and 14 days. Incompatible pairings resulted in an interaction zone where mycelia from each isolate stopped growing. Accumulation of the red food color in the hyphal tips formed a red line between incompatible pairings. Compatible interactions resulted in an intermingling of mycelia with no interaction zone. Of the 60 sclerotia collected from the Guaíra region, 32 produced viable isolates. However, only 18 of them could be maintained and used in this study. Mycelial compatibility analysis grouped the 18 isolates into 2 MCGs (Table 1). The five isolates from Minas Gerais, a distance of approximately $500 \mathrm{~km}$ from our sampling site in São Paulo belonged to the same two MCG (Table 1). Mycelial compatibility group 1 (MCG1) consisted of isolates CASS 1D, CASS 4, CASS 13, CASS 14, CASS 19, CASS 20, BI $\mathrm{F}_{2} \mathrm{PI}_{8}$ and $\mathrm{P}_{2} \mathrm{PNI}_{21}$. All of the remaining isolates belonged to MCG2. A similar finding was reported in Canada, where $S$. sclerotiorum isolates from a single field had several different MCGs and these same MCGs were distributed over a large area (Kohn, 1995).

In an attempt to determine genetic variability and to find new genetic markers among these isolates, ITS/RFLPs and a number of different PCR-based primers were tested. DNA from the $S$. sclerotiorum isolates was extracted with a CTAB protocol described by Meinhardt et al. (2002).

The ITS PCR amplifications were conducted with the ITS1 and ITS4 primers described by White et al. (1990). The reaction conditions were identical to those used for the other PCR primers (listed below) except for the annealing

TABLE 1 - Isolates of Sclerotinia sclerotiorum utilized in this study, their hosts, origins and groupings based on MCG and on PCR amplification of telomere sequence-based primers

\begin{tabular}{|c|c|c|c|c|}
\hline \multirow{2}{*}{ Isolate } & \multirow{2}{*}{ Host $^{1}$} & \multirow{2}{*}{ Origin } & \multicolumn{2}{|c|}{ groups } \\
\hline & & & $\mathrm{MCG}^{2}$ & Telo $^{3}$ \\
\hline CASS 1C & common bean & Guaíra-SP & 2 & 2 \\
\hline CASS 1D & common bean & Guaíra-SP & 1 & 2 \\
\hline CASS 4 & common bean & Guaíra-SP & 1 & 1 \\
\hline CASS 5 & common bean & Guaíra-SP & 2 & 2 \\
\hline CASS 6 & common bean & Guaíra-SP & 2 & 2 \\
\hline CASS 8 & common bean & Guaíra-SP & 2 & 2 \\
\hline CASS 9 & common bean & Guaíra-SP & 2 & 2 \\
\hline CASS 10 & common bean & Guaíra-SP & 2 & 2 \\
\hline CASS 11 & common bean & Guaíra-SP & 2 & 2 \\
\hline CASS 12 & common bean & Guaíra-SP & 2 & 2 \\
\hline CASS 13 & common bean & Guaíra-SP & 1 & 1 \\
\hline CASS 14 & common bean & Guaíra-SP & 1 & 1 \\
\hline CASS 16 & common bean & Guaíra-SP & 2 & 2 \\
\hline CASS 17 & common bean & Guaíra-SP & 2 & 2 \\
\hline CASS 18 & common bean & Guaíra-SP & 2 & 2 \\
\hline CASS 19 & common bean & Guaíra-SP & 1 & 1 \\
\hline CASS 20 & common bean & Guaíra-SP & 1 & 1 \\
\hline CASS 22 & common bean & Guaíra-SP & 2 & 2 \\
\hline $\mathrm{BI}_{14}$ & Potato & Unai/Bomfinópolis-MG & 1 & 1 \\
\hline $\mathrm{F}_{2} \mathrm{I}_{1}$, & common bean & Unai/Bomfinópolis-MG & 2 & 2 \\
\hline $\mathrm{F}_{2} \mathrm{PI}_{8}$ & common bean & Unai/Bomfinópolis-MG & 1 & 2 \\
\hline $\mathrm{F}_{1} \mathrm{~W}_{9}$ & common bean & Unai/Bomfinópolis-MG & 2 & 2 \\
\hline $\mathrm{P}_{2} \mathrm{PNI}_{21}$ & bell peppers & Unai/Bomfinópolis-MG & 1 & 2 \\
\hline
\end{tabular}

${ }^{1}$ Common bean variety Carioca $80 \mathrm{SH}$. Potato and bell pepper varieties are unknown. ${ }^{2}$ Mycelial compatibility groups

${ }^{3}$ Groupings based on telomere primer TeloA1R analysis. 
temperature, which was $50{ }^{\circ} \mathrm{C}$. The PCR products were alcohol precipitated with 0.1 volume $3 \mathrm{M}$ sodium acetate $\mathrm{pH} 5.2$ and 2 volumes of $100 \%$ ethanol. Approximately $0.5 \mu \mathrm{g}$ of resuspended DNA was digested with 3 units of restriction enzyme according to manufacturer's recommendations (New England BioLabs). All PCR products and restriction fragments were separated by gel electrophoresis on either $2 \%$ agarose or $8 \%$ polyacrylamide. Gels were stained with ethidium bromide, visualized under UV light and digitally documented with the BioRad Fluor-S MultiImager system.

Six different four-base-pair recognition site (HaeIII, $H h a \mathrm{I}, M b o \mathrm{I}$, MseI, MspI, Taq $\alpha \mathrm{I}$,) restriction enzymes were used in this study. The ITS1-5.8S-ITS2 regions of the rDNA of these isolates produced an uncut amplicon of approximately $600 \mathrm{bp}$ in length. These amplicons were digested with the restriction enzymes and none of the enzymes revealed any difference among the isolates (data not shown). This confirms the findings of Kohn et al. (1991), who reported no polymorphisms within this region in undigested amplicons.

Microsatellite PCR primers designated MS3435 $=$ $(\mathrm{GTG})^{5}, \mathrm{MS}_{12} 1^{4}=(\mathrm{GACA})^{4}$, and MS4342 ${ }^{4}=(\mathrm{TGTC})^{4}$ were tested (Buscot et al., 1996; Geistlinger et al., 1997; Longato \& Bonfante, 1997; Meinhardt et al., 2002). The touch down PCR protocol was used with these microsatellite primers (Don et al., 1991) and the primers were not paired during these reactions. All PCRs were allowed to complete 35 cycles and utilized 1 unit of Platinum Taq DNA polymerase / reaction (Gibco/BRL). Magnesium chloride concentrations were 1.5 $\mathrm{mM}$, while standard concentrations of DNA (100 ng), dNTPs $(200 \mu \mathrm{M})$ and primers $(50 \mathrm{nM})$ were used. All reactions were hot started for $10 \mathrm{~min}$ at $92{ }^{\circ} \mathrm{C}$ prior to the amplification cycles ( 35 cycles of: $94{ }^{\circ} \mathrm{C}$ for $1 \mathrm{~min}, 40{ }^{\circ} \mathrm{C}$ for $1 \mathrm{~min}$, and 72 ${ }^{\circ} \mathrm{C}$ for $2 \mathrm{~min}$ ) and were followed with a final $10 \mathrm{~min}$ cycle at $72{ }^{\circ} \mathrm{C}$ before ending the reaction. Of the microsatellite PCR primers tested only one, MS3 $121^{4}=(\mathrm{GACA})^{4}$, produced a polymorphic banding pattern (Figure 1). The isolates CASS4, 13, 14, 19 and 20 had an intense band at $850 \mathrm{bp}$, while the other isolates had faint or no bands at this size. One unfortunate drawback of this particular microsatellite primer was that it was not possible to eliminate the faint bands produced in the water control. These background bands were below $600 \mathrm{bp}$, which was smaller than the amplicons produced. The MS31214 microsatellite banding patterns for the five isolates from Minas Gerais were identical to the São Paulo isolates, with only $\mathrm{BI}_{14}$ having the intense $850 \mathrm{bp}$ polymorphic band (data not shown). All of the isolates that produced the intense 850 bp band grouped with MCG1 isolates. Three MCG1 isolates (CASS $1 \mathrm{D}, \mathrm{F}_{2} \mathrm{PI}_{8}$, and $\mathrm{P}_{2} \mathrm{PNI}_{21}$ ) lacked the intense $850 \mathrm{bp}$ band.

Chromosomal telomere sequences were also utilized as PCR primers (Guzmán \& Sánchez, 1994; Meinhardt et al., 2002; Pipe \& Shaw, 1997). The concentration of primers, DNA and other components were the same as described above and were not paired. The amplification of TeloA1R primers at $40{ }^{\circ} \mathrm{C}$ produced genotypic banding patterns that separated the isolates into two genotypic groups (Telo-group 1 and Telo-
$1001 \mathrm{C} 1 \mathrm{D} 4 \quad 5 \quad 6 \quad 8 \quad 91011121314161718192022$ C 100

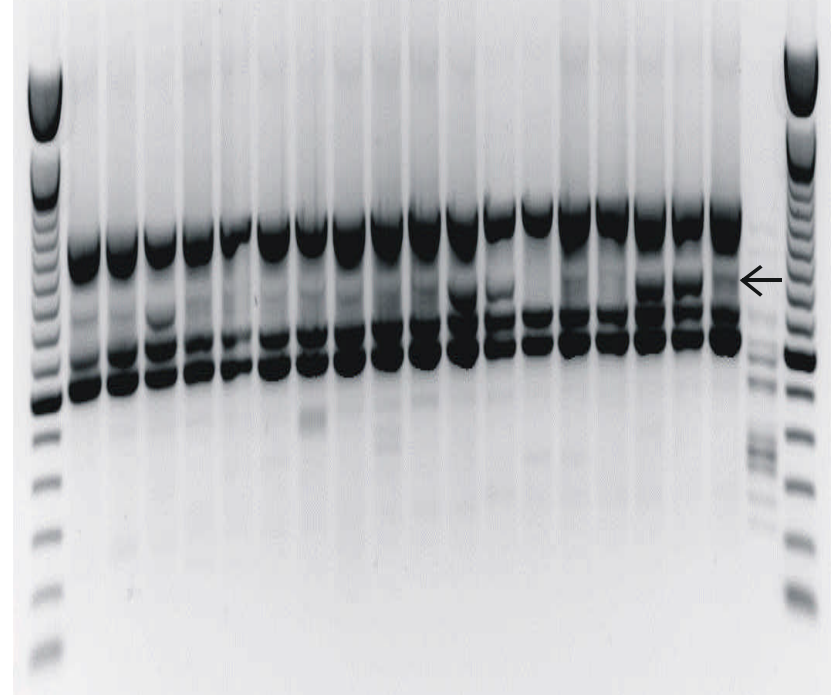

FIG. 1 - Microsatellite analysis of Sclerotinia sclerotiorum isolates amplified with the MS3121 (GACA) ${ }^{3}$ primer. PCR amplicons were separated on a $\mathbf{2 . 0 \%}$ agarose gel in $0.5 \mathrm{X}$ TBE. Bands were stained with ethidium bromide and visualized on a UV light source. The arrow indicates the $850 \mathrm{bp}$ polymorphic band. The sizes of the other amplified bands are approximately 600, 700 and $1100 \mathrm{bp}$ in length. 100 indicates the use of the 100 base-pair-size standard (Gibco). $\mathrm{C}$ indicates the PCR water control. This Figure is the negative image of the stained gel.

group 2) (Figure 2). Telo-group 1 isolates (CASS 4, 13, 14, 19 and 20) produced an intense band at $600 \mathrm{bp}$. Telo-group 2 isolates (CASS 1C, 1D, 5, 6, 8, 9, 10, 11, 12, 16, 17, 18, and 22) produced four to five bands that ranged from 2200,1300 , 1000,900 , and $400-450 \mathrm{bp}$. When the annealing temperature was increased to $45^{\circ} \mathrm{C}$ most of the high molecular weight bands disappeared, while only the $600 \mathrm{bp}$ and 400-450 bp were conserved (data not shown).

When compared to the five isolates from Minas Gerais, from three different hosts, identical banding patterns for the Telo-group 1 and group 2 isolates were observed for the TeloA1R primer (data not shown). Four of the isolates from beans and peppers were identical to the Telo- group 2 isolates, while the isolate $\mathrm{BI}_{14}$, from potatoes, produced the $600 \mathrm{bp}$ fragment identical to the Telo-group 1 isolates.

All of the Telo-group 1 isolates were of the same mycelial compatibility group (MCG1) (Table 1) and all had identical MS3 $121^{4}$ polymorphic banding patterns. The three MCG1 isolates that failed to show a polymorphic banding for MS3121 ${ }^{4}$ had Telo-group 2 banding patterns. All of the MCG2 isolates were grouped as Telo-group 2 isolates and had identical MS31214 banding patterns (Table 1). One possible explanation for these observations is that there is some genetic variation within MCG 1 isolates, and that the 
$1001 C 1 D \quad 4 \quad 5 \quad 6 \quad 8 \quad 91011121314161718192022$ C 100

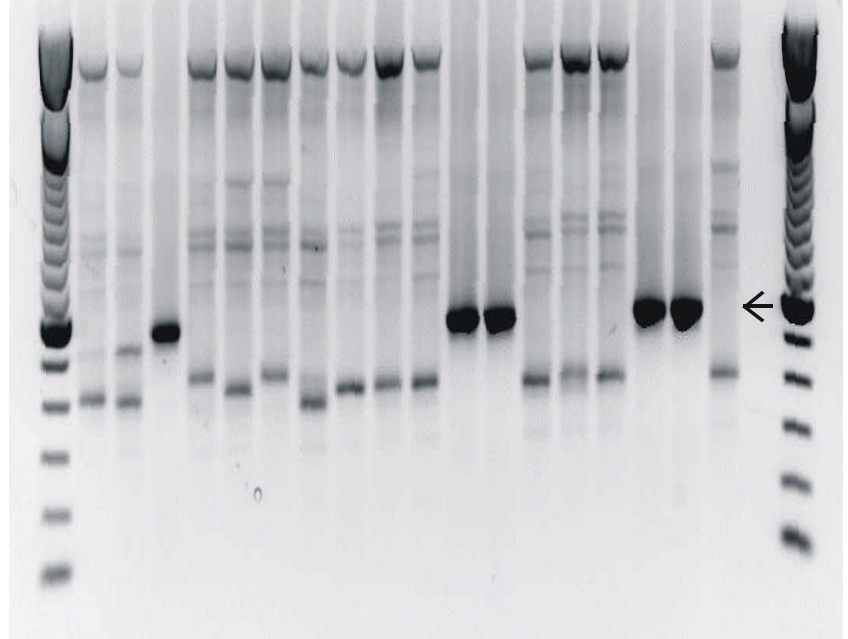

FIG. 2 - PCR amplicons of Sclerotinia sclerotiorum isolates from Guaíra-SP amplified with the telomere sequence-based primer TeloA1R. Amplification reactions were run on a $2.0 \%$ agarose gel in $0.5 \mathrm{X}$ TBE. Bands were stained with ethidium bromide and visualized with a UV light source. The arrow indicates the 600 bp polymorphic band that is present in Telo-group 1 isolates. 100 indicates the use of the 100 base-pair-size standard (Gibco). C indicates the PCR water control. This Figure is the negative image of the stained gel.

isolates within MCG2 appear to be genetically uniform. It is unclear what the exact role or significance of these telomeresequence-associated variations are at this time, however the genotypic variation observed among the Telo-group 1 isolates was confirmed with the microsatellite primer MS312 $1^{4}$. Furthermore, it is not clear what the MCG1 isolates that group with Telo-group 2 represent, however, one possible role is that they could correspond to a genetic bridging group between the two MCG populations.

The work of Kohn et al. (1991), who utilized a number of different genetic markers; RFLPs, nuclear and mitochondrial probes, found that each MCG sampled was genotypically unique and genetically uniform. These data along with those of Cubeta et al., (1997) and Kohn et al., (1995) have shown that $S$. sclerotiorum populations (cabbage in Eastern North Carolina and canola in Canada) to be mainly clonal. While this study supports their findings by showing the genetic uniformity of the Brazilian MCGs, represented by the low number of MCGs, it also shows that microsatellite and telomere sequence-based PCR primers (especially the PCR primer TeloA1R) are able to show some genetic variability within MCGs of S. sclerotiorum. The 23 isolates of $S$. sclerotiorum analyzed in this study appear to be closely related with limited genetic variability. This suggests that $S$. sclerotiorum may have been introduced in the studied areas and/or it has had only a limited amount of time or opportunity to undergo genetic change. Finally, based on these initial results, a larger study with more complete samplings and analyses of the genetic variations of Brazilian isolates of $S$. sclerotiorum is needed in order to confirm and expand these findings.

\section{ACKNOWLEDGEMENTS}

We thank Dr. Cláudia B. Monteiro-Vitorello for providing the fungal isolates from the state of Minas Gerais. We also thank Thaís R. P. Pascholati for her technical support.

\section{LITERATURE CITED}

BUSCOT, F., WIPF, D., DI BATTISTA, C., MUNCH, J.C., BOTTON, B. \& MARTIN, F. DNA polymorphism in morels: PCR/RFLP analysis of the ribosomal DNA spacers and microsatellite-primed PCR. Mycological Research 100:63-71. 1996.

CUBETA, M.A., CODY, B.R., KOHLI, Y. \& KOHN, L.M. Clonality in Sclerotinia sclerotiorum on infected cabbage in Eastern North Carolina. Phytopathology 87:1000-1004. 1997.

DON, R.H., COX, P.T., WAINWRIGHT, B.J., BAKER, K. \& MATTICK, J.S. Touchdown PCR to circumvent spurious priming during gene amplification. Nucleic Acids Research 19:4008. 1991.

FORD, E.J., MILLER, R.V., GRAY, H. \& SHERWOOD, J.E. Heterokaryon formation and vegetative compatibility in Sclerotinia sclerotiorum. Mycological Research 99:241-247. 1995.

GEISTLINGER, J., MAQBOOL, S., KAISER, W.J. \& KAHL, G. Detection of microsatellite fingerprint markers and their Mendelian inheritance in Ascochyta rabiei. Mycological Research 101:1113-1121. 1997.

GUZMÁN, P.A. \& SÁNCHEZ, J.G. Characterization of telomeric regions from Ustilago maydis. Microbiology 140:551-557. 1994.

KOHN, L.M., CARBONE, I. \& ANDERSON, J.B. Mycelial interactions in Sclerotinia sclerotiorum. Experimental Mycology 14:255-267. 1990.

KOHN, L.M., STASOVSKI, E., CARBONE, I., ROYER, J. \& ANDERSON, J.B. Mycelial incompatibility and molecular markers identify genetic variability in field populations of Sclerotinia sclerotiorum. Phytopathology 81:480-485. 1991.

KOHN, L.M. The clonal dynamics in wild and agricultural plantpathogen populations. Canadian Journal of Botany 73:S1231S1240. 1995.

LONGATO, S. \& BONFANTE, P. Molecular identification of mycorrhizal fungi by direct amplification of microsatellite regions. Mycological Research 101:425-432. 1997.

MEINHARDT, L.W., WULFF, N.A., BELLATO, C.M. \& TSAI, S.M. Genetic Analyses of Rhizoctonia solani Isolates from Phaseolus vulgaris Grown in the Atlantic Rainforest Region of São Paulo, Brazil. Fitopatologia Brasileira. 2002. (in press).

PIPE, N.D. \& SHAW, D.S. Telomere-associated restriction fragment length polymorphisms in Phytophthora infestans. Molecular 
Telomere and microsatellite primers reveal diversity among Sclerotinia sclerotiorum isolates...

Plant Pathology On-line Mppol/1997/1124pipe. 1997.

VALARINI, P.J. \& SPADOTTO, C.A. Identification of survival niches of pathogens in irrigated agriculture of Guaíra, São Paulo State. Pesquisa Agropecuária Brasileira. 30:1239-1243. 1995. WHITE, T.J., BRUNS, T., LEE, S., \& TAYLOR, J. Amplification and direct sequencing of fungal ribosomal RNA genes for phylogenetics. In: Innis, M.A., Gelfand, D.H.,. Sninsky J.J, \& White, T.J. (Eds.). PCR protocols: A Guide to Methods and Applications. Academic Press, San Diego. 1990. pp.315322. 